\title{
Mauritania: its wildlife and a coastal park Jacques Verschuren
}

Most of Mauritania's populations of large mammals have been exterminated or severely depleted by hunting. The Mauritanians usually do not hunt birds, however, and as a result the avifauna are protected, albeit somewhat passively. The Parc National du Banc d'Arguin is an exceptionally rich coastal area, attracting huge concentrations of waders in the European winter and impressive nesting colonies of birds in the summer, including eastern white pelicans, greater flamingos and royal terns. Although the birds are probably safe, the Park's mammals are not, and the last few dorcas gazelles need urgent protection from poachers.

Mauritania is a very large country with a human population density among the lowest on earth. Three-quarters of the country is covered by the Sahara Desert, and useful agricultural land is

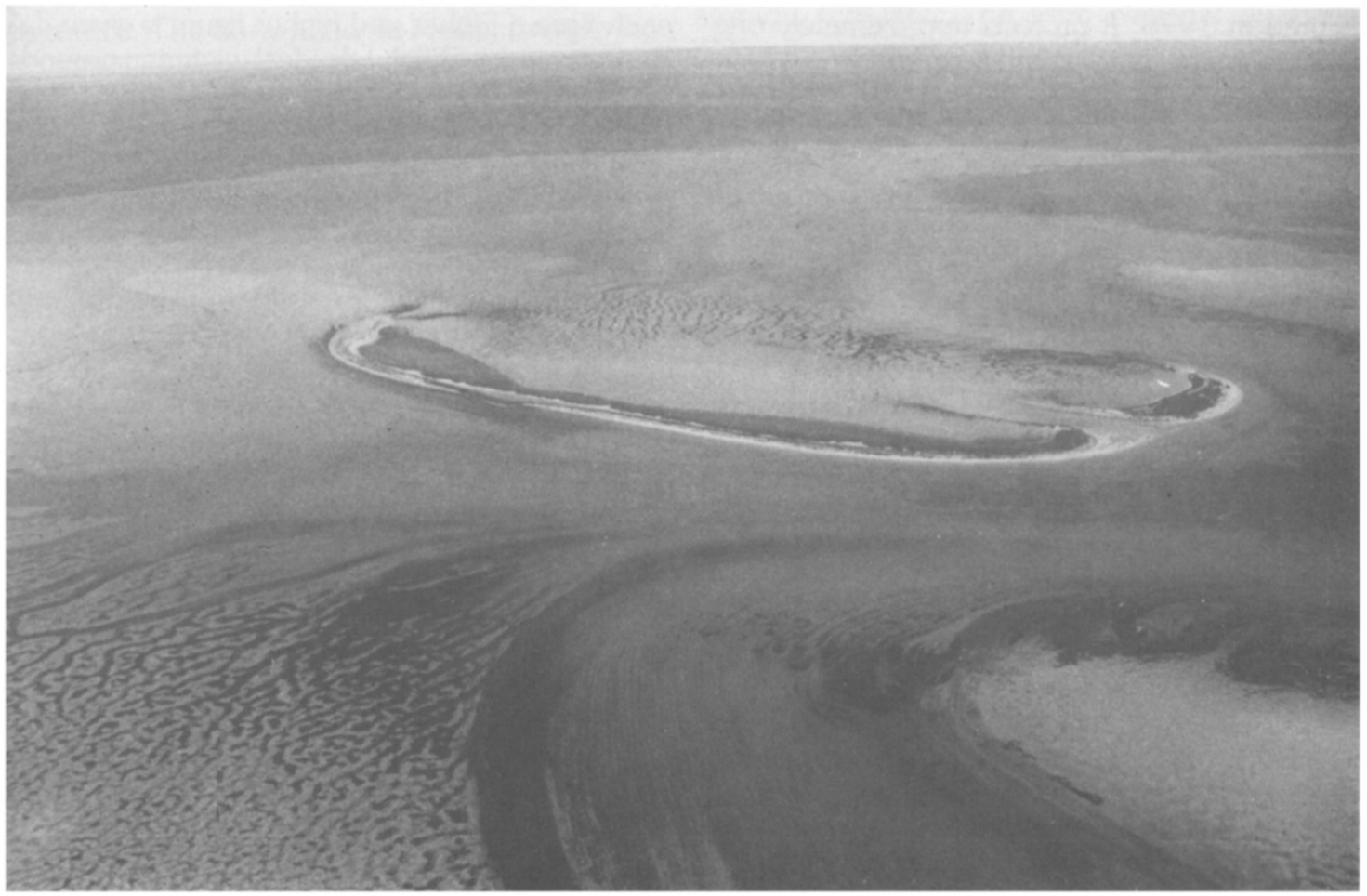


confined to the vicinity of the Senegal River, on the border with Senegal. Two major contrasts exist in this country: it is a place where the Atlantic and the Sahara meet, and a point of contact between the Arab world and the African world. Nouakchott's Palaearctic fauna makes European zoologists feel quite at home, while $200 \mathrm{~km}$ to the south, the fauna is of a generally Afrotropical nature, including hornbill and weaver birds.

\section{A park mainly for the birds}

At the request of the Mauritanian authorities and in collaboration with the World Wildlife Fund, the author prepared a management plan for the principal national park: the Banc d'Arguin (Verschuren, 1984). The major problem in Mauritania is progressive desertification: the lack of rain is becoming more and more acute, and the pasture land is disappearing. Even in the coastal desert area, where there used to be one or two good annual rains before 1960 , several years sometimes pass without a single drop of rain.

The Parc National du Banc d'Arguin was officially decreed in 1978. It protects approximately one million hectares $(2,471,000$ acres $)$, of which one-

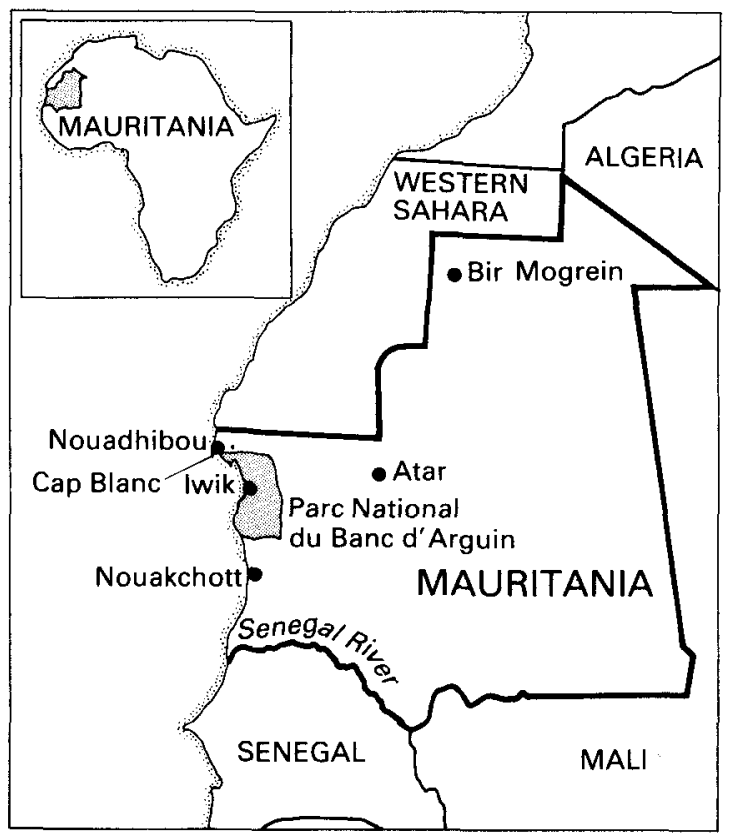

Mauritania, showing the location of the Banc d'Arguin. The boundaries with Algeria and Western Sahara are not officially recognized.

222 third is coastal desert, one-third is sea and the rest consists mainly of extraordinarily high and low areas of land, which are partially uncovered at low tide: the extensive mud-flats are very productive biologically. It is also in the Banc d'Arguin that we find the northernmost mangrove swamp on Africa's Atlantic coast.

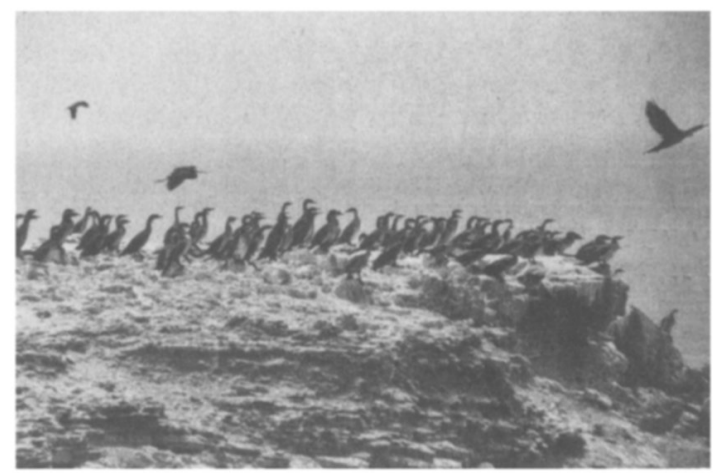

Cormorants nest in large numbers at the Banc d'Arguin (J. Verschuren).

The area is of major interest for its birds. Several scientists have painstakingly counted them, and each time a higher and higher figure is given. Le Banc provides absolutely ideal wintering grounds for waders from Europe and northern Asia. Censuses carried out by NOME in 1981 give a total figure of about 2,244,000 waders, which is probably lower than the actual number; the total included 818,000 dunlin Calidris alpina, 543,000 bar-tailed godwit Limosa lapponica, 366,000 knot $C$. canutus and 175,000 curlew sandpiper C. ferruginea (NOME, 1981). The sight of these huge colonies of waders, concentrated on the small roosts available at high tide, is tremendously exciting. The number of nesting birds is equally spectacular; they gather on islands that are completely protected from the main predator, the golden jackal Canis aureus. Various authors observed (although numbers are subject to confirmation) the nests of nearly 2000 pairs of eastern white pelicans Pelecanus onocrotalus, 4000 pairs of reed cormorants Phalacrocorax africanus, 1000 western reef heron Egretta gularis, 3000 greater flamingo Phoenicopterus ruber (which nest on the rocks), 5300 pairs of royal terns Stema maxima, and the very numerous white spoonbill Platalea leucorodia.

It is admirable that this extraordinary avifauna is Oryx Vol 19 No 4 
in no way disturbed by the human population of the country. The Imraguens, traditional fishermen who use sailing boats, never hunt and are not interested in taking eggs. The Mauritanians, generally, do not hunt birds and the result is that the birds receive a remarkable amount of passive protection.

The situation is, unfortunately, not so good for the large mammals. During recent decades, hunting has caused the extermination of the large ungulates. The addra gazelle Gazella dama and the gemsbok Oryx gazella no longer exist in the Park. Some hundreds of dorcas gazelles Gazella dorcas survived here for a while, with one population living, surprisingly, on the island of Tidra. Unfortunately, the effect of hunting is still considerable and, during our land surveys and aerial censuses, we located fewer than a dozen individuals of this gazelle. The cheetah Acinonyx jubatus is also extinct. An interesting mammal fauna still does exist, however. The striped hyaena Hyaena hyaena is one example, and some of these animals have become adapted to a diet that often consists mostly of the remains of sea turtles. The honey badger Mellivora capensis also survives and the golden jackal Canis aureus is common everywhere and can often be seen.

Cetaceans are numerous in the waters of the Park: the humpback dolphin Sousa teuszii is often seen here at the northern limit of its range. Cap Blanc near Nouadhibou, which, in fact, forms an annex of the Parc National du Banc d'Arguin, is occupied by a dozen individuals, all adults, of the rare Mediterranean monk seal Monachus monachus. They are a familiar sight here, undisturbed by the numerous fishermen, and provide a classic tourist attraction. A large colony exists further north, on the Atlantic coast, but it is at present inaccessible.

The fish fauna of the Banc d'Arguin-like that of the open sea-is one of the richest on earth, unfortunately plundered by foreign fishermen, in particular trawlers, from all parts. Several species of turtle live in the Banc d'Arguin. The green turtle Chelonia mydas is common and has been hunted since time immemorial by the Imraguen fishermen. Although this subsistence hunting does not constitute a threat in itself, there is, unfortunately, intense pressure from traders selling them to Mauritania: wildlife and coastal park

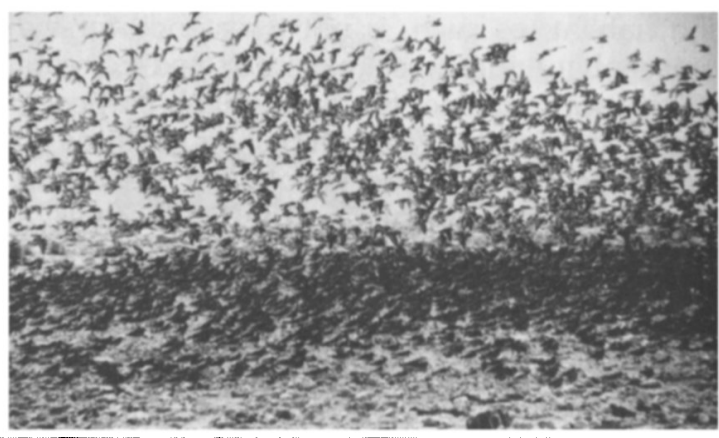

Several million waders winter at the Banc d'Arguin (J. Verschuren).

tourists at Dakar, Nouadhibou, and other places. Its breeding areas are not well known.

What are the threats that face this exceptional natural reserve of comparable value, in global terms, to the Waddenzee in Western Europe? In the short term, it may be unfortunate that any surveillance is rather incidental, and protection is only assured in theory. The birds are safe, but guards would be essential to put an end to the poaching of the last gazelles, if indeed it is not already too late. The Parc National du Banc d'Arguin is administratively autonomous, but dependent on the Presidency of the Republic. It is hoped, therefore, that the authorities will shortly take the necessary action. A scientific research station has been established at lwik, on the coast, in the heart of the reserve, but it is often inaccessible. All activities in the Banc d'Arguin are determined by the extreme environmental conditions: the almost total absence of fresh water, almost total desert, and the perilous sea passages between the islands.

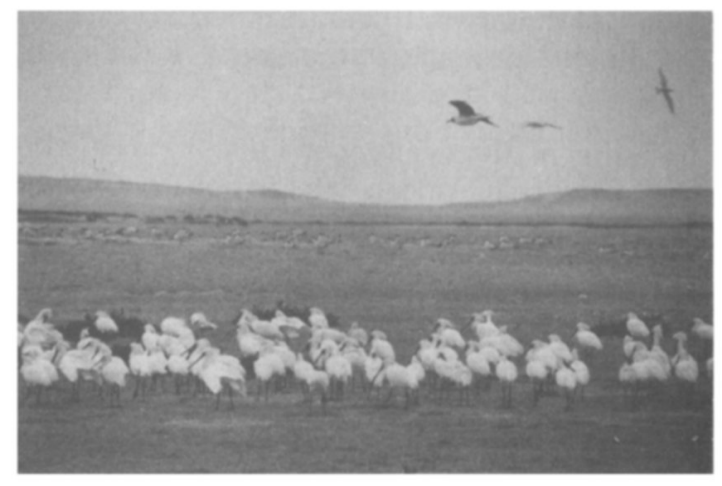

Many white spoonbills nest at the Banc d'Arguin (J. Verschuren). 
The habitat, as such, is not threatened for the foreseeable future; reclamation of land from the sea is not possible for agricultural purposes. Limited grazing, tolerated officially, is practised by shepherds, but its impact is not great, at least for the time being. Pollution from the sea is a potential risk, given the intense maritime traffic and the industry at Nouadhibou. There is a project to construct a main high road between Nouadhibou and Nouakchott. The route has not been settled, but it will pass near the Park. Remarkably, in a feasibility study, account was taken of and priority given to the need for the conservation of the Park. It is encouraging that large scientific research projects, with international collaboration, are planned for this major wild area. Thus, we can be fairly optimistic about the future of this beautiful natural reserve, whose only immediate major problem is the preservation of the last dorcas gazelles. It is hoped that the Park will soon be included in UNESCO's list of World Heritage Sites.

\section{Hope for an international park}

What is the situation concerning the rest of the wildlife and reserves in Mauritania? It would be foolish to assert that it is good, because the majority of large mammals have been exterminated by intensive hunting; and although the majority of birds are not hunted, bustards are hunted intensively. Barbary sheep Ammotragus lervia still live in fairly large numbers in the Adrar Mountains. It is likely that herds of addax Addax nasomaculatus still survive in the desert expanse in the east of the country, but the rest of the desert fauna is threatened with extinction, and no emergency protective measures have been taken.

The Senegal River valley contains a very different habitat, typically African, vitalized by the river and the rains, which, unfortunately, are becoming less and less abundant. Some elephants Loxodonta africana live by the middle reaches of the river, where they can be seen on both banks. In the south, lions Felis leo probably still survive, as well as kob Kobus kob. The hippopotamus of the Senegal River has finally disappeared, as has the giraffe and the buffalo. One large mammal, the wart hog Phacochoerus aethiopicus, has 224 remained in large numbers. It is not hunted, since it is never eaten, by the local population, but it is hunted for sport, no doubt too intensively, by foreigners. Wart hogs were seen in the Parc National du Banc d'Arguin before the drought years.

The Senegal delta provides wintering grounds and important resting places for migrant waterfowl and waders, in particular ruff Philomachus pugnax, which are given intensive protection in the very beautiful Parc National du Djoujd in Senegal. It is strongly hoped that similar protection will be given to the Mauritanian section and that, one day, an international park will be created in the area. The effect of dams on the Senegal River, which are already under construction, will obviously be significant for the delta ecosystem. Certain consequences will be beneficial, but the effects of such a major change in habitat should be monitored, especially since it is the principal freshwater region immediately south of the Sahara desert. Measures are particularly needed to preserve the Parc du Djoujd in Senegal. 'Theoretical' reserves exist in various regions of Mauritania, but they are not monitored in practice. Hunting, using falcons, is not uncommon in Mauritania.

Let us hope, finally, that the inhabitants of this country, which is 100 per cent Islam, will recall this very beautiful saying from the prophet Mohammed:

'Do not pillage. Do not plunder. Respect the trees'.

\section{Acknowledgments}

We thank the authorities of the Republic of Mauritania for supporting this work. Grateful thanks go to the many scientists who worked or are still working in Mauritania, and to WWF International, which subsidized the expedition and to the Institut Royal des Sciences Naturelles in Belgium.

\section{References}

NOME, 1981. Wintering Waters on the Banc d'Arguin. Comm. 6. Waddensee Working Group (including a general bibliography on the subject).

Verschuren, J. 1984. Plan Directeur Préliminaire. Parc National du Banc d'Arguin. R.I. Mauritanie, WWF-IUCN, $1-139$.

Dr Jacques Verschuren, Institut Royal des Sciences Naturelles de Belgique, 29 rue Vautier, Brussels 1040, Belgium.

Oryx Vol 19 No 4 